\title{
RAPIDLY PROGRESSIVE GLOMERULONEPHRITIDES, DIAGNOSTIC AND THERAPEUTIC URGENCY
}

\author{
Cristina Buhoara, Mircea Penescu
}

\begin{abstract}
Rapidly progressive glomerulonephritides are relatively rare but serious disorders of diverse etiology, which share some clinical features: rapid evolution, progressive to renal failure, often accompanied by oliguria or anuria. They are characterized histopathologically by an intense extracapillary proliferation, with the development of crescents (semilunar lesions) in over $50 \%$ of examined glomeruli. The following pathological entities are referred to as rapidly progressive glomerulonephritides: ANCA-positive pauci-immune vasculitides (microscopic polyangiitis, granulomatosis associated with microscopic polyangiitis, allergic granulomatosis associated with microscopic polyangiitis), extracapillary proliferative glomerulonephritides by immune complexes and glomerulonephritides by anti-glomerular basement membrane antibodies. Due to major histopathological and functional complications, their evolution to death or renal replacement therapy occurs within 6-24 months after the diagnosis, if they are not treated, but the evolution is favorably influenced by aggressive immunosuppression, whether or not associated with plasmapheresis.
\end{abstract}

Key words: glomerulonephritides, antibodies, crescents, vasculitides, immunosuppression.

\section{Rezumat}

Glomerulonefritele rapid progresive sunt afecțiuni relativ rare, dar grave, de etiologie diversă, care au în comun câteva caracteristici clinice: evoluție rapidă, progresivă spre insuficiență renală, însoțită adesea de oligurie sau anurie. Sunt caracterizate histopatologic de proliferare extracapilară intensă, cu formarea de semilune (crescens) în peste 50\% dintre glomerulii examinați. Sub denumirea de glomerulonefrite rapid progresive sunt încadrate următoarele entități patologice: vasculite pauci-imune ANCA pozitive (poliangeită microscopică, granulomatoză asociată poliangeitei microscopice, granulomatoză alergică asociată poliangeitei microscopice), glomeulonefrite proliferative extracapilare prin complexe imune și gomerulonefrite prin anticorpi anti-membrană bazală glomerulară. Prin complicațiile majore histopatologice și funcționale, evoluția acestora spre deces, sau tratament substitutiv renal are loc în 6-24 de luni de la diagnostic, dacă nu sunt tratate, dar favorabil influențată de imunosupresie agresivă, asociată sau nu cu plasmafereză.

Cuvinte cheie: glomerulonefrite, anticorpi, semilune, vasculite, imunosupresie. 


\section{INTERNAL}

\section{General Reviews}

\section{Introduction}

Rapidly progressive glomerulonephritides are relatively rare diseases of diverse etiology, which share some clinical features: rapid evolution, progressive to renal failure, often accompanied by oliguria or anuria. They are histopathologically defined by an important extracellular proliferation with the development of crescents in more than $50 \%$ of analyzed glomeruli. Necrosis of the capillary wall is initiated by immunological abnormalities, and the initiation mechanism can be evaluated by immunofluorescence examination of renal biopsy. Identification of the type of immunological injury shows clinical utility, allows the adaptation of the therapy and is the basis of the classification of the type of injuries: anti-glomerular basement membrane antibodies (linear deposits), anti-neutrophil cytoplasmic antibodies (ANCAs - few or absent deposits), immune complexes (granular deposits).

Rapidly progressive glomerulonephritides are not a homogeneous pattern of renal impairment, the only common aspect is the rapid evolution and the poor prognosis if appropriate treatment is not applied in a timely manner. However this denomination hides several clinical categories with various immunological an histopathological particularities, resulting in a wide diversity of diseases with different features.
Pauci-immune glomerulonephritides ANCA-positive vasculitides: epidemiology, clinical and histopathological aspects

ANCA-positive vasculitides represent about $80 \%$ of all RPGN cases, with an incidence of 7-10 cases per million inhabitants per year in the United States ${ }^{(1)}$. From the point of view of geographic distribution, it was observed that microscopic polyangiitis is more common in southern areas, while granulomatosis associated with polyangiitis is more common in northern Europe, and people of color on the African continent have a lower incidence of ANCA-positive vasculitides than Caucasians $^{(4)}$.

ANCA vasculitides are manifested as a systemic disease or as a disease restricted to an organ; respiratory tract, skin, kidney are often involved.

From the clinical point of view, they have a polymorphic character, which makes recognition difficult, thus explaining the long time (2-6 months) between the onset of the symptomatology and establishing the positive diagnosis.

In a large proportion of patients (about $60 \%$ ), the clinical appearance is not complete at the time of diagnosis; moreover, about a quarter of patients experience severe lifethreatening manifestations both after diagnosis and after treatment initiation ${ }^{(11)}$. 
The clinical presentation associates acute nephritic syndrome with subacute degradation of renal function. The kidney disease can be isolated but usually it is accompanied by general or respiratory manifestations.

The mean creatinine at presentation varies around $5 \mathrm{mg} / \mathrm{dL}$. Histopathologically, lesions of necrotizing glomerulonephritis are found with extracapillary proliferation phenomena (crescents), pauci-immune on immunofluorescence and no electron microscopy deposits (Figure 1); the examined tissue fragment, comprising at least 10 glomeruli, is considered appropriate to conclude the histopathological diagnosis (10).

They are characterized by necrotic lesions of small vessels: arterioles, capillaries, venules. Antibodies directed against the neutrophil cytoplasm (ANCA) present in the serum of patients in more than $80 \%$ of cases are required for diagnosis, and are also involved in the pathogenesis ${ }^{(3)}$.

These disorders show a maximum frequency in people over 60 years of age, but were detected in a biopsy of three in individuals over 80 years of age with acute kidney injury, so they can also be seen as conditions of the elderly, although they may occur at any age ${ }^{(2)}$.

This category includes the following anatomical-clinical forms: microscopic polyangiitis (MAP), granulomatosis associated with microscopic polyangiitis (Wegener's granulomatosis - GPA), allergic granulomatosis associated with microscopic polyangitis (Churg-Strauss syndrome EGPA).

These can be associated in different proportions with positive serology for pANCA (anti-myeloperoxidase (MPO) antibodies) or cANCA (anti-proteinase 3 antibodies).
Glomerulonephritides by antiglomerular basement membrane antibodies (anti-GBM antibodies) Clinical and histopathological considerations

It is the rarest pathogenic form of extracapillary proliferative glomerulonephritis produced by antibodies directed against the non-collagen domain of $\alpha 3$ and $\alpha 5$ chains of type IV collagen which is found only in the structure of glomerular and alveolar basement membranes ${ }^{(16)}$. The condition can be presented as rapidly progressive glomerulonephritis, haemorrhagic alveolitis or as a combination of the two ${ }^{(14,15)}$.

Onset is generally acute, with severe acute nephritic syndrome and / or pulmonary haemorrhage, possibly manifested only as post-hemorrhagic anemia without external bleeding. It may be preceded by general manifestations (myalgia, polyarthralgia, low fever), but these symptoms are less intense than in vasculitides.

Pulmonary haemorrhage occurs in more than half of the patients and may be driven by intercurrent infections, hyperhydration, but also by the advanced stage of renal insufficiency. It has a variable intensity, ranging from a few occurrences of hemoptysis sputum to severe bleeding, with severe anemia and respiratory failure.

The acute nephritic syndrome dominated by the rapidly progressive decline of renal function is associated with frequent systemic manifestations; the association of oliguria with macroscopic hematuria is characteristic. Anti-GBM antibodies are found in an increased plasma titer, thus in correlation with the severity of renal impairment in over $80-90 \%$ of patients ${ }^{(18)}$. Renal biopsy puncture is mandatory for confirmation of diagnosis. 


\section{INTERNAL}

\section{General Reviews}

\section{Proliferative extracapillary glomeru- lonephritides by immune complexes}

They are considered to be the most common pathogenic form of crescentic glomerulonephritis ${ }^{22,23,24)}$, found more commonly in elderly patients, with equal distribution between genders ${ }^{(25,26)}$. Extracapillary proliferation with the occurrence of crescents in more than $50 \%$ of the examined glomeruli is associated with lesions typical for a particular glomerulopathy: membranous nephropathy, cryoglobulinemia, membranoproliferative glomerulonephritides (MPGNs) (Figure 3), IgA nephropathy (Figure 4), SLE (Figure 2.1, Figure 2.2), glomerulonephritides associated with infections. The clinical presentation is dominated by the acute nephritic syndrome with rapidly progressive degradation of the renal function, and is associated more commonly than other types of glomerulonephritides with crescents, hypertension, and proteinuria (even in the nephrotic domain). The immunological aspect is specific to the underlying nephropathy (cryoglobulinemia, hypocomplementemia, rheumatoid factor, anti-PLA2R antibodies); anti-GBM antibodies and ANCA are usually absent.

\section{Treatment and prognosis of rapidly progressive glomerulonephritides}

Initiating treatment is urgent because each lost moment increases the risk of irreversible destruction of the kidney and / or the death of the patient. At this time, the goal of treatment is to rapidly induce remission and prevent relapses. Induction of remission involves a decrease in inflammation and acute destructive lesions. In generalized forms methylprednisolone and cytotoxics such as cyclophosphamide are used, possibly associated with plasmapheresis in severe forms or in forms refractory to this treatment (7). Maintaining remission involves combating autoimmunity with cytostatic agents (azathioprine, mycophenolate mofetil or methotrexate) associated with low doses of prednisone. In the case of ANCA-positive vasculitides, it was observed that without treatment the mortality at 1 year is $80 \%$, but with adequate immunosuppressive therapy, survival at 5 years increases to $75 \%{ }^{(5)}$. Old age, dependence on dialysis and pulmonary haemorrhage decrease survival rate at 5 years to $35 \%$. Regarding renal function, approximately $25 \%$ of patients progress to ESRD ${ }^{(5)}$. The best predictor of renal results is baseline serum creatinine as well as the extent of renal lesions and fibrosis revealed by renal biopsy. Between 24 and $87 \%$ of patients are dialysis-dependent upon presentation ${ }^{(13)}$. The response to treatment is seen in most patients during the first 5 months of treatment ${ }^{(8)}$.

However, resistance to treatment is manifested by $8-23 \%$ of the individuals diagnosed. The percentage may reach up to $50 \%$ in those with severely altered renal function (GFR $<10 \mathrm{~mL} / \mathrm{min}$ ) ${ }^{(8)}$. Although 

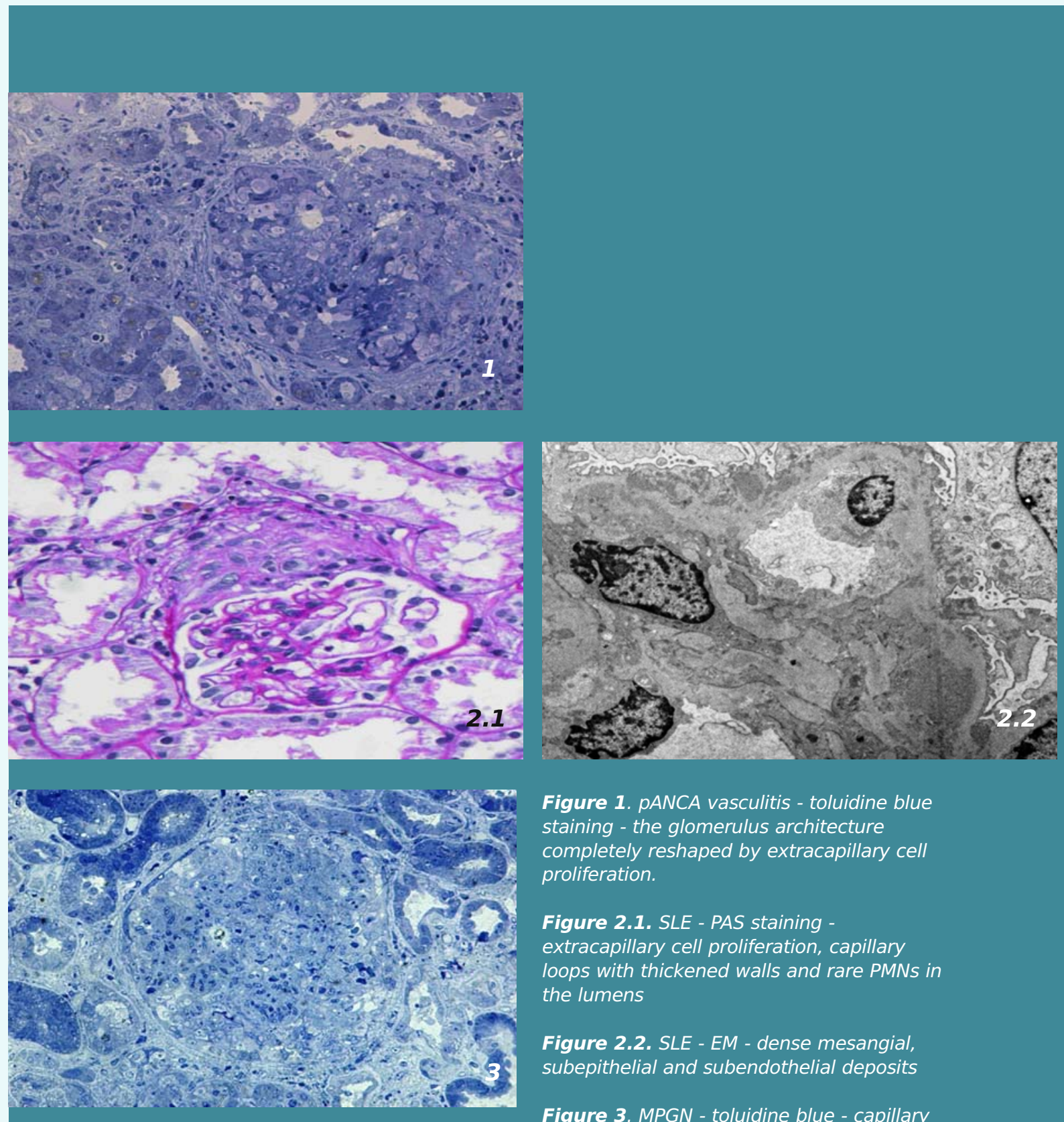

Figure 1. pANCA vasculitis - toluidine blue staining - the glomerulus architecture completely reshaped by extracapillary cell proliferation.

\section{Figure 2.1. SLE - PAS staining -}

extracapillary cell proliferation, capillary

loops with thickened walls and rare PMNs in the lumens

Figure 2.2. SLE - EM - dense mesangial, subepithelial and subendothelial deposits

Figure 3. MPGN - toluidine blue - capillary loops with lobular pattern and extracapillary cell proliferation

Figure 4. IgA Nephropathy - Mesangial IgApositive with arborescent pattern

* Collection of the "Dr. Carol Davila" Clinical

Nephrology Hospital

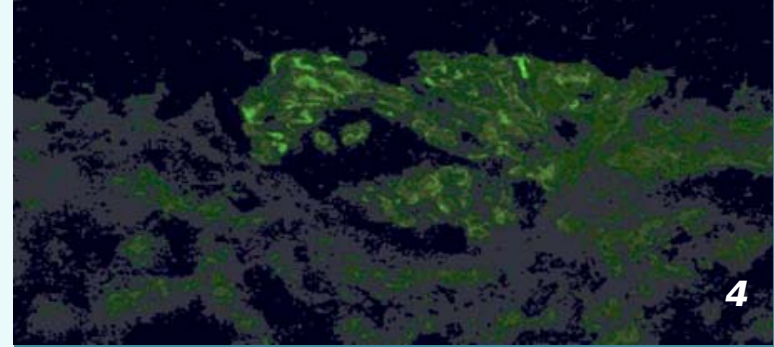

Table 4. Results of Cox Proportional-Hazards Regression, Adjusted for Age, Sex, and Other Potential Confounders. 


\section{INTERNAI}

\section{General Reviews}

remission can be induced in most patients, about $40 \%$ of patients experience relapse, indicating the need for strict monitoring ${ }^{(1)}$.

Treatment of glomerulonephritides with antiGBM antibodies should be initiated urgently regardless of kidney function level and has the objective of rapidly reducing the level of antiGBM antibodies; the treatment consists of pulses with methylprednisolone, plasmapheresis and cyclophosphamide or renal transplantation ${ }^{(19)}$. In the absence of therapy, the death and / or irreversible degradation of renal function occur in more than $90 \%$ of cases. The main causes of early death are pulmonary haemorrhage - by associating acute renal failure with post-hemorrhagic anemia - followed by the occurrence of infections ${ }^{(20)}$. Prognosis depends on the degree of renal impairment at the time of diagnosis, which is closely related to the level of circulating anti-GBM antibodies. Thus, the survival of the patient and the kidney at 1 year is quantified as follows: $100 \%-95 \%$, when serum creatinine at presentation is less than $5.7 \mathrm{mg} / \mathrm{dL}, 83 \%$ - $82 \%$ when serum creatinine is greater than $5.7 \mathrm{mg} / \mathrm{dL}$ and 65 , and $8 \%$ when dialysis was required from the time of diagnosis ${ }^{(21)}$. Pulmonary haemorrhage may be the leading cause of death in patients with glomerulonephritis by anti-GBM antibodies, but in those who survive pulmonary sequelae are usually minor (17). Characteristic of glomerulonephritis with anti-GBM antibodies is that relapses are rare; they occur on average 4-7 years after diagnosis and have a frequency of $2-14 \%$, and may affect the kidneys and the lung ${ }^{(19)}$.

In the case of glomerulonephritides associated with infections, immunosu-ppression should be discussed only in life-threatening forms and after appropriate infection control ${ }^{(1)}$. The side effects of immunosuppression (infection, sterility, neoplasms), as well as those of longterm corticotherapy (infection, disorders of lipid, carbohydrate, and hydroelectrolytic metabolism, ulcer, osteoporosis) are important and further complicate the already deteriorated status of the patients.

\section{Conclusions}

Despite significant advances in the understanding of the immune mechanisms underlying the pathogenesis of these categories of kidney disease and the ever wider and more accurate histopathological diagnosis modalities, issues related to incomplete efficacy, treatment toxicity and infectious complications persist.

It is absolutely essential that the diagnosis of rapidly progressive glomerulonephritides be early and allow for the prompt application of appropriate therapy. Respecting these sinequa-non conditions ensures remarkable success, with survival at 5 years over $80 \%$, as shown by the statistical analysis of the batch of 
patients with rapidly progressive glomerulonephritides in the "Dr. Carol Davila" Clinical Nephrology Hospital. However, the existence of cases incompletely responding to treatment or relapses sometimes even during maintenance therapy support the need to look for new and more effective therapeutic regimens.

\section{References}

1. Glassock R. J., Adler S. G., Ward H. J., et al. Primary glomerular diseases. In: Brenner B. M., Rector F. C., editors. The Kidney. 4th. Philadelphia, Pa, USA: Saunders; 1991. pp. 1182-1279.

2. Moutzouris DA et al, 2009.

3. Davies DJ et al, 1982; van der WoudeFJ et al, 1985; Falk RJ et al, 1988; Jennette JC et al, 1994.

4. Charles Jennette J., Falk R. J., McGregor J. G. Comprehensive Clinical Nephrology. 5th. Elsevier; 2015. Renal and systemic valculitis.

5. Jennette J. C., Olson J. L., Schwartz M. M., Silva F. G. Pauci-immune and ANCA-mediated crescentic glomerulonephritis and vasculitis. Heptinstall's Pathology of the Kidney. (6th) 2007;1(chapter 14)

6. Watnick S., Dirkx T. Kidney disease. In: Papadakis M. A., McPhee S. J., Rabow M. W., editors. Current Medical Diagnosis \& Treatment 2015. New York, NY, USA: McGrawHill; 2014.

7. Miloslavsky E.M., Specks U., Merkel P.A. Clinical outcomes of remission induction therapy for severe antineutrophil cytoplasmic antibody-associated vasculitis. Arthritis Rheum. 2013;65:2441-2449. (PubMed)

8. de Groot K., Harper L., Jayne D.R. Pulse versus daily oral cyclophosphamide for induction of remission in antineutrophil cytoplasmic antibody-associated vasculitis: a randomized trial. Ann Intern Med. 2009;150:670-680. (PubMed)

9. Hilhorst M., Wilde B., van Paassen P. Improved outcome in anti-neutrophil cytoplasmic antibody (ANCA)associated glomerulonephritis: a 30-year follow-up study. Nephrol Dial Transplant. 2013;28:373-379. (PubMed)

10. Robson J., Doll H., Suppiah R. Damage in the ANCAassociated vasculitides: long-term data from the European vasculitis study group (EUVAS) therapeutic trials. Ann Rheum Dis. 2015;74:177-184. (PubMed)

11. Andreiana I, Stancu S, Avram A, Taran L, Mircescu G: ANCA positive crescentic glomerulonephritis outcome in a Central East Europan cohort: a retrospective study. BMC Nephrol (2015) 15:90.doi:10.1186/s12882-015-0091-8.
12. Falk RJ, Hogan S, Carey TS, Jennette JC. Clinical course of anti-neutrophil cytoplasmic autoantibody-associated glomerulonephritis and systemic vasculitis. The Glomerular Disease Collaborative Network. Ann Intern Med. 1990;113:656-663. (PubMed)

13. Pendergraft $W F$, Preston GA, Shah $R R$, et al. Autoimmunity is triggered by CPR-3(105-201), a protein complementary to human autoantigen proteinase-3. Nat Med. 2004;10:72-79. (PubMed)

14. Wilson CB, Dixon FJ. Anti-glomerular basement membrane antibody-induced glomerulonephritis. Kidney Int. 1973;3:74-89. (PubMed)

15. Salama $A D$, Levy JB, Lightstone L, Pusey $C D$. Goodpasture's disease. Lancet. 2001;358:917-20. (PubMed)

16. Pusey CD. Anti-glomerular basement membrane disease. Kidney Int 2003; 64: 1535-1550 (PubMed)

17. Kluth DC et al, 1999

18. Cui Z, Zhao J, Jia $X Y, Z$ Zhu $S N$, Jin $Q Z$, Cheng $X Y$, Zhao $M H .:$ Anti-glomerular basement membrane disease: Outcomes of different therapeutic regimens in a large single-center Chinese cohort study. Medicine (Baltimore) 90: 303-311, 2011

19. Kidney Disease Improving Global Outcomes (KDIGO) Glomerulonephritis Work Group: KDIGO clinical practice guideline for glomerulonephritis. Kidney Int Suppl 2: 139-274, 2012

20. Mircescu G, Mandache E, Stancu S-Glomerulopatiile, Editura Enciclopedica, Bucuresti 2016; 973-39-0814-2

21. Salama AD, Dougan T, Levy JB, Cook HT, Morgan SH, Naudeer S, Maidment G, George AJ, Evans D, Lightstone L, Pusey CD.: Goodpasture's disease in the absence of circulating anti-glomerular basement membrane antibodies as detected by standard techniques. Am J Kidney Dis 39: 1162-1167, 2002

22. Jennette JC, Falk RJ, Andrassy K, et al. Nomenclature of systemic vasculitides. Proposal of an international consensus conference. Arthritis Rheum. 1994;37:187-192. (PubMed)

23. Jennette JC. Rapidly progressive crescentic glomerulonephritis. Kidney Int. 2003;63:1164-1177. (PubMed)

24. Jennette JC, Falk RJ. Clinical and pathological classification of ANCA-associated vasculitis: what are the controversies? Clin Exp Immunol. 1995;101(suppl 1):18-22. (PMC free article) (PubMed)

25. Falk RJ. ANCA-associated renal disease. Kidney Int. 1990;38:998-1010. (PubMed)

26. Pettersson EE, Sundelin B, Heigl Z. Incidence and outcome of pauci-immune necrotizing and crescentic glomerulonephritis in adults. Clin Nephrol. 1995;43:141-149. (PubMed). 